\title{
Valorisation of Agri- and Aquaculture Residues via Biogas Production for Enhanced Industrial Application
}

\author{
Júlio Ximenes ${ }^{1}$, André Siqueira ${ }^{1}$, Ewa Kochańska ${ }^{2}$ and Rafał M. Łukasik ${ }^{3, *(D)}$ \\ 1 PISCIS Industry Trade LTDA, Sitio Baixa do Arroz, s/n, Jaguaribara 63490-000, Brazil; \\ julio.ximenes@gmail.com (J.X.); andrefsiqueira01@gmail.com (A.S.) \\ 2 Research and Innovation Centre Pro-Akademia, 9/11 Innowacyjna Street, \\ 95-050 Konstantynów Łódzki, Poland; ewa.kochanska@proakademia.eu \\ 3 National Laboratory for Energy and Geology (LNEG, I. P.), Bioenergy and Biorefineries Unit, Estrada do Paço \\ do Lumiar 22, 1649-038 Lisbon, Portugal \\ * Correspondence: rafal.lukasik@lneg.pt
}

Citation: Ximenes, J.; Siqueira, A.; Kochańska, E.; Łukasik, R.M

Valorisation of Agri- and Aquaculture Residues via Biogas Production for Enhanced Industrial Application. Energies 2021, 14, 2519. https://doi. org/10.3390/en14092519

Academic Editor: Changman Kim

Received: 1 April 2021

Accepted: 25 April 2021

Published: 27 April 2021

Publisher's Note: MDPI stays neutral with regard to jurisdictional claims in published maps and institutional affiliations.

Copyright: (c) 2021 by the authors. Licensee MDPI, Basel, Switzerland. This article is an open access article distributed under the terms and conditions of the Creative Commons Attribution (CC BY) license (https:// creativecommons.org/licenses/by/ $4.0 /)$.

\begin{abstract}
Climate changes are nowadays reality and affect all aspects of everyday life. One of the places where these changes influence the society the most is the Brazilian Ceara region and Jaguaribara basin that suffer long-lasting, devastating drought cycles. They have a dramatic negative impact on local economy, forcing change in business models. This work presents the valorisation of wastes and residues from local fish, prawns, and the vegetable-cultivation industry via biogas production forced to adapt to these new circumstances. Along a single year, as much as 189.74 tonnes of wastes and residues can be processed by the biogas production facility, producing as much as 94 GJ of cooling energy and 1 tonne of biofertiliser monthly. Even for such a small biogas production facility, the NPV is positive already after 11 years; its IRR is $6.2 \%$, and accumulated ROI for 20 years of operation is as high as $77.8 \%$. This work demonstrates that a valorisation of industrial wastes and residues via biogas production is a feasible solution for a specific industrial scenario addressing new socio-economic challenges for the particular enterprise.
\end{abstract}

Keywords: energy; fish residues; anaerobic digestion; waste valorisation; biofertiliser; biogas

\section{Introduction}

Over the last few decades, Brazil has experienced devastating cycles of prolonged drought. The most affected region of Brazil is Ceará, the Northeast state regularly affected by consecutive years of insufficient rainfall. This drives to the frequent serious water limitations including severe situations such as a declaration of a state of emergency in some cities, including the state capital, Fortaleza. These restrictions strongly influence the local industries, too. The most affected are those focused on the primary production, e.g., tilapia fish and associated industries. Only in 2015, 219,000 metric tonnes of Nile tilapia (Oreochromis niloticus), which is one of the most common varieties in Brazil, was caught for further processing or direct consumption [1]. Tilapia viscera oil is a valuable feedstock for the biofuel industry [2] and other value-added applications [3]. Therefore, a significant water shortage in the entire region and inadequate water management together with a limited rainfall and high evapotranspiration caused by the elevated temperature around the year have a significant influence on the local business environment. This in turn has a direct impact on the local communities as a significant part of the population is directly employed in the agriculture and fish farming areas. Furthermore, constantly increasing Ceará's municipalities and progressing industrialisation put additional pressure on water demand from the nearby Jaguaribe basin. To answer these needs and to mitigate undesired climate changes, in 2003, a $6700 \mathrm{Mm}^{3}$ [4] Castanhão reservoir was commissioned. Its main aim was to increase storage capacity and ensure water flow throughout the year, as well as to prevent potential flooding once the climate condition changed. Nevertheless, 
just to picture the devastating effect of drought, it is worth mentioning that the lowest registered water reserves were observed in February of 2019 with only $3.75 \%$ of Açude Castanhão total capacity occupied [5]. So low water amount has a dramatic effect on the concentrations of dissolved salts and oxygen levels, making the quality of water very low and inappropriate for any agricultural and aquaculture activities. Another serious consequence of the Açude Castanhão water-volume reduction is the accumulation of nutrients causing a significant increase of algal density and cyanobacteria blooms, resulting in an extensive eutrophication. In consequence, in 2015, a tilapia fish population was radically reduced, causing losses for local economies estimated at 18 million Brazilian Reals [6] (ca. 2.7 million $€, 1 €=6.6$ Brazilian Reals).

The main challenge worldwide, including in Brazil, is waste management [7]. For this reason, biogas production seems to be a viable solution for a waste management and as a source of additional economic benefits especially when organic fraction is considered as a part of biorefinery concept [8]. Despite successful development of several other technologies in the renewable energy sector, especially bioethanol and biodiesel, biogas has not reached a similar level of interest in Brazil [9]. It is especially unusual because the biogas production potential in Brazil is estimated at the level of 57 and 84 billion $\mathrm{m}^{3}$ annually. The major source of biogas can be the anaerobic digestion of cattle manure that can produce on average a 26.3 TWh/year of electricity. Summing this up with the electricity production from the organic fraction of municipal residues, the overall electricity production in Brazil is somewhere between 31.52 and $48.72 \mathrm{TWh} /$ year [10]. Hence it is peculiar that such little attention has been paid to the sector [11] especially since these numbers demonstrate that as much as $5 \%$ of all installed capacity in Brazil, i.e., 4.5-6.9 GW, could be satisfied by biogas if successfully implemented [10]. One of the reasons for this might be a specificity of Brazil, especially in the areas of policy support, e.g., underdeveloped public policies and technological, e.g., logistics issues, technical, and technological difficulties, etc. These constrains drive to questions about the economic feasibility of biogas production. Nevertheless, Dardot Campello et al. demonstrated that with adequate development of public policies, i.e., the electricity generation from biogas production in the anaerobic treatments of sewage sludge, the majority of municipalities with a population of only 50,000 inhabitants would have an average payback period of only 2.61 year [12]. Similar conclusions on the economic feasibility of biogas installations are valid for other countries and feedstocks, too. For example, Wattanasilp et al. demonstrated that industrial cassava starch wastewater treatment towards biogas production is a value-added option for valorisation of such residues [13]. These and other examples [14] are of special importance when considering that biogas production can be extended beyond the use of waste valorisation for electricity purposes and can be a relevant factor for the enrichment of the renewable natural gas system. In this context, Assunção et al. concluded that the integration of key advances in biogas production in the technology roadmap for natural gas can significantly widen the potential for implementation of this technology for better valorisation of waste streams leading to more enhanced energy-based upgrading [15].

From the feedstocks point of view, numerous raw materials were considered for biogas production. Yet, use of fish residues for biogas is rather limited. It is especially relevant as fish processing in particular from aquaculture has had significant increase in the last decade [16]. Recirculation aquaculture systems (Figure 1) have gained importance due to the comparative advantages over conventional flow-through systems, especially in terms of the control as well as possibility of reducing water consumption and waste release. 

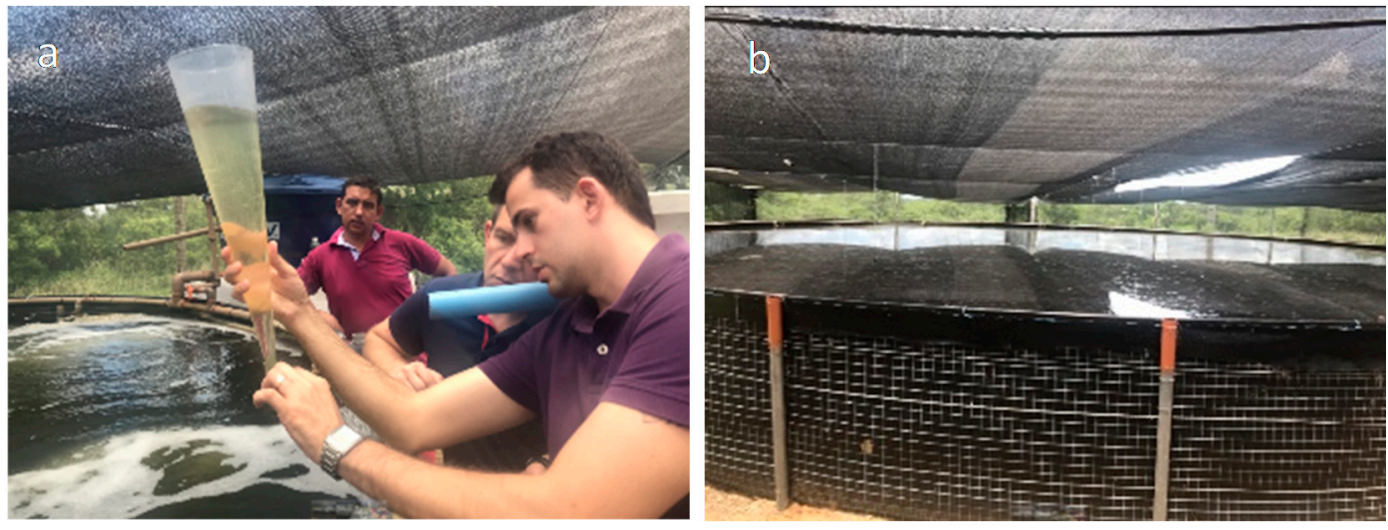

Figure 1. Recirculation aquaculture system for tilapia production exploited in PISCIS company.

On the other hand, it is also remarkable that there is no biogas plant in Ceará region, since this state is one of the pioneer states in Brazil in development of renewable energies, being the first to have a commercial wind farm, in 1999, and the first commercial solar farm, installed in Tauá in 2011. Hence, renewable sources have a strong impact in Ceará's energy matrix [17]. This work seeks to fill the gap and aims to demonstrate a real ind ustrial scenario of conversion of wastes and residues to value-added application in the specific enterprise in Brazil. In this context, this work shows how biogas production as a valorisation approach of the organic residue and waste fractions from tilapia and prawns farming and from tomato and lettuce cultivation responds to the challenges caused by the water shortage and to what extent it provides new business opportunities for the local economies in the Ceará region.

\section{Methodology}

In this work, a production of biogas from agri- and aquaculture wastes and residues of the Ceará industry is demonstrated. The methodology section presents technological, economic assumptions compiled together with data regarding a production of commercial goods of PISCIS with information about feedstock available for the biogas production in a new anaerobic digestion facility.

\subsection{Technological Approach}

\subsubsection{Case Study}

The analysed case study is based on current activities, i.e., the oil production from the tilapia viscera. The considered scenario seeks to preserve the key activity of the company by expanding the enterprise's offer of fish filleting and a production of prawns, lettuce, and cherry tomato. The feedstock used for the biogas production is composed of viscera oil production waste residues from the fish filleting mixed with wastes from prawns farming and lettuce and tomato cultivations. The considered scenario is schematically presented in Figure 2.

\subsubsection{Anaerobic Digestion Installation Consideration}

The biogas installation analysed in this work is constituted by container-skid construction, initial tank with a mixer, substrate pump system, biogas cleaning system, biogas flare, automation, biogas tank, and fermentation tank. Such installation can process up to $140 \mathrm{~m}^{3}$ of biogas daily with a caloricity of $70 \%$ methane. The electricity generators, especially for low biogas quantities, are characterised by low efficiency (e.g., 25-30\%); thus, instead of electricity production, a gas chiller for cooling energy production able to serve for preservation of food products obtained by the enterprise was considered in this work. Efficiencies of gas chillers are usually higher than electricity generators. For a considered scale, the efficiency of gas chillers is at the level of $68 \%$, giving $36.3 \mathrm{~kW}$ of cooling energy 
with a continuous operation mode or $72.6 \mathrm{~kW}$ of cooling energy with a peak system work according to the needs for a $12 \mathrm{~h}$ work regime [18].

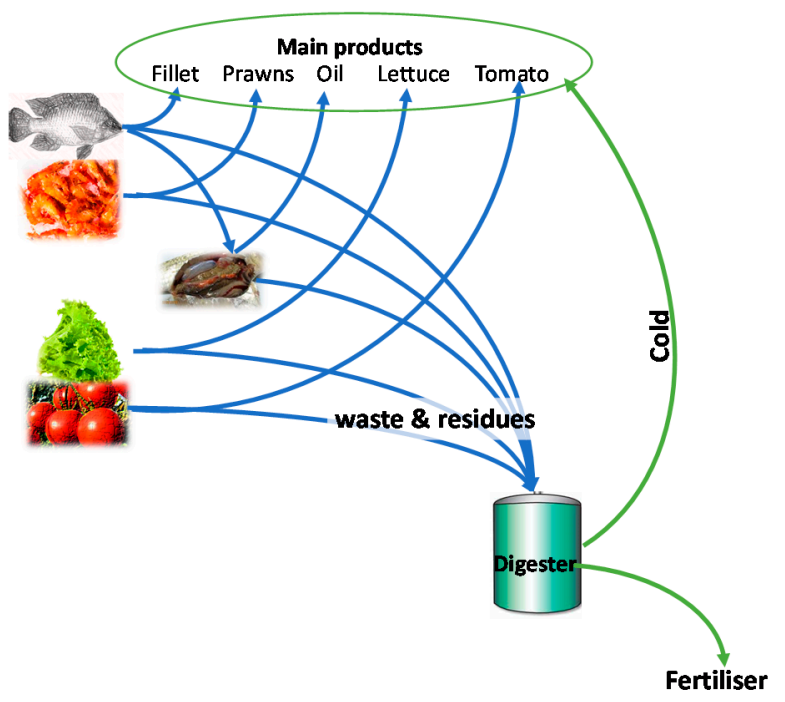

Figure 2. The graphical presentation of case study with a biogas valorisation approach integrated into the main activity of company.

\subsection{Economic Assumptions}

\subsubsection{CAPEX and OPEX}

In the economic analysis, the CAPEX of the biogas plant including gas chiller for $66.5 \mathrm{k} €$ together with transport to the installation site, local customs, and installation itself was considered to be $90.8 \mathrm{k} €[18]$. Furthermore, associated construction works were considered to be at the level of $10 \%$ of the equipment cost. A total investment cost was established to be $97.4 \mathrm{k} €$. OPEX was estimated at the level of $5 \%$ of the total installation cost, i.e., $4870.04 € /$ yearly. The bank loan for 5 years ( 60 months) with a fixed rate of $7 \%$ per annum for a total value of investment was considered, too.

\subsubsection{Goods and Commodities Costs and Prices}

The information about the production costs and related sale prices of prawns and tilapia and its derivatives (tilapia fillets and viscera oil) as well as waste disposal costs were obtained from locally operated PISCIS [19]. The wholesale prices of vegetables in Brazil were taken from elsewhere [20], and the local production cost was given by PISCIS on the basis of their long-lasting experience in the considered region [19]. The cost of cooling energy was determined on the basis of information presented elsewhere [21], and the substitution of mineral fertiliser [22] was assumed to determine the price of digestate (biofertiliser).

\subsubsection{Economic Indicators}

On the basis of the obtained results, the net present value (NPV), internal rate of return (IRR), and return on investment (ROI) were calculated. The NPV is defined as $\mathrm{NPV}=\sum_{t=1}^{n} \frac{R_{t}}{(1+i)^{t}}$, where $R_{t}$ is net cash inflow-outflows during a single period $t, i$ is a discount rate or return that could be earned in alternative investments, and $t$ is number of timer periods. IRR can be calculated from the following formula: $0=\mathrm{NPV}=\sum_{t=1}^{n} \frac{C_{t}}{(1 * I R R)^{t}}-C_{0}$, where $C_{t}$ is net cash inflow during the period $t, C_{0}$ is total initial investment cost, IRR is the internal rate of return, and $t$ is the number of time periods. The ROI was calculated using the following expression $R O I=\frac{\sum_{t=1}^{n} R_{t}-C_{O}}{C_{O}}$. 


\subsection{Production Data}

\subsubsection{Main Commodities Manufactured by PISCIS}

To support the economic analysis, the production scale of tilapia, prawns, lettuce, and tomato of PISCIS enterprise is presented in Table 1.

Table 1. The scale of PISCIS production [19].

\begin{tabular}{cc}
\hline Product & Amount (Tonnes/Year) \\
\hline Tilapia & 174 \\
Prawns & 40 \\
Lettuce $^{\text {a }}$ & 238,000 \\
Tomato & 250 \\
\hline
\end{tabular}

a units/year.

\subsubsection{Biogas Feedstock Availability}

On the basis of information about the tilapia, prawns, lettuce, and tomato production given in Table 1, the amount of wastes and residues envisaged to be available as a feedstock for the biogas production was calculated and the results are collected in Table 2.

Table 2. The feedstock availability for the biogas production.

\begin{tabular}{cccc}
\hline Description & Value & Unit & Reference \\
\hline Fish production cycles per year & 2 & - & {$[19]$} \\
Viscera content in fish & 10 & $\%$ & {$[19]$} \\
Oil extraction yield from viscera & 35 & $\%$ & {$[19]$} \\
Density of pure fish oil & 0.87 & $\mathrm{~kg} / \mathrm{L}$ & {$[23]$} \\
Dry matter content of effluent from oil extraction & 8 & $\%$ & {$[19]$} \\
Fish wastes from filleting not considering viscera & 50 & $\%$ & {$[19]$} \\
Dry matter content of tilapia filleting wastes & 76 & $\%$ & {$[24]$} \\
Dead fish rate & 5 & $\%$ & {$[25]$} \\
Prawns waste rate & 40 & $\%$ & {$[19]$} \\
Lettuce weight & 22 & $\%$ & {$[26]$} \\
Lettuce waste rate & 0.30 & $\mathrm{~kg} / \mathrm{unit}$ & this work \\
Dry matter content of prawns' shells & 20 & $\%$ & {$[19]$} \\
Tomato waste rate & 17 & $\%$ & {$[27]$} \\
Dry matter content of tomato & 20 & $\%$ & {$[19]$} \\
\hline
\end{tabular}

\subsubsection{Biogas Production Facility Assumptions}

Table 3 resumes the information about the requirements regarding the feedstock for biogas production unit. The theoretical biogas yield and methane content were established at the very conservative regions in comparison to other typically used feedstocks [29] or for fish residues [30,31].

Table 3. The biogas production facility requirements.

\begin{tabular}{|c|c|c|c|}
\hline Description & Value & Unit & Reference \\
\hline Days of operation & 365 & days/year & \\
\hline Operation hours & 8760 & $\mathrm{~h} /$ year & \\
\hline $\begin{array}{c}\text { Maximal dry matter (DM) content in } \\
\text { biodigester }\end{array}$ & 12 & $\%$ & {$[18,21,29]$} \\
\hline Organic dry matter content in DM (ODM) & 90 & $\%$ & {$[21,29]$} \\
\hline Dry matter content used by bacteria for growth & 5 & $\%$ & {$[21,29]$} \\
\hline Biogas yield & 400 & $\mathrm{~m}^{3} / \mathrm{t} \mathrm{DM}$ & average value from [29] \\
\hline Methane content & 70 & $\%$ & [29] \\
\hline Energy in $1 \mathrm{~m}^{3}$ biogas & 6.5 & kWh & [29] \\
\hline
\end{tabular}




\section{Results and Discussion}

The technical and economic feasibility of the analysed case study was performed considering the production scale of main products and the corresponding amount of feedstock for the biogas production. Figure 3 demonstrates the Sankey diagram including main PISCIS product streams and corresponding streams of wastes and residues available for valorisation via biogas.

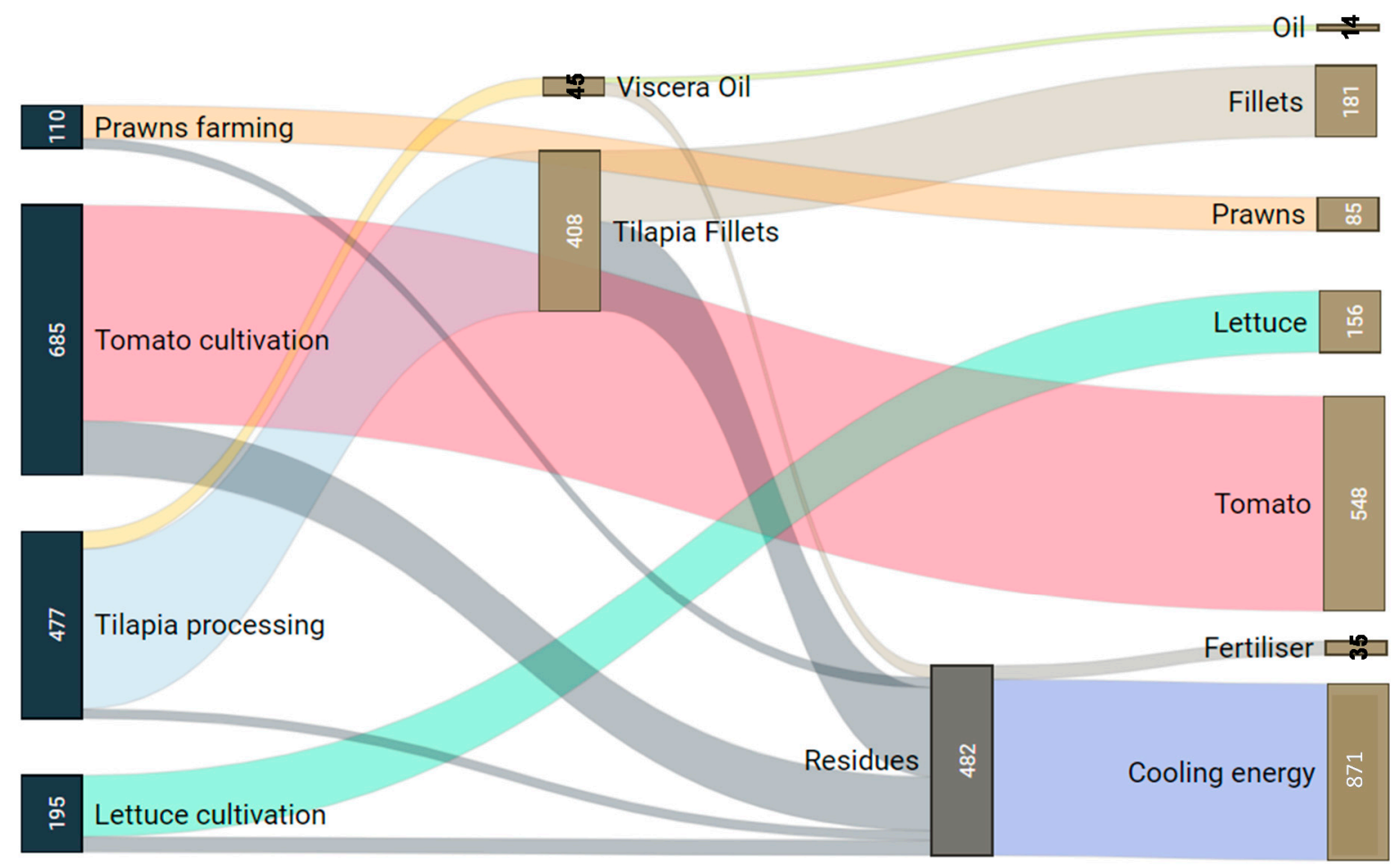

Figure 3. The Sankey diagram presenting main streams of the considered case study with all main products and biogas production value-chain. All data are given in kg/day with exception of cooling energy that is given in $\mathrm{kWh}$ in $12 \mathrm{~h}$ regime.

As shown in Figure 3 and from data given in Tables 2 and 3, the overall volume of wastes available for biogas product was estimated at the level of $482 \mathrm{~kg} /$ day with a dry matter content of $48.7 \%$. Considering the biogas production yield as given in Table 2, the established amount of wastes and residues from PISCIS activity would allow generating as much as $125-140 \mathrm{~m}^{3} /$ day of biogas. Hence, pondering a potential electricity production in a continuous operation mode, ca $11.5 \mathrm{kWe}$, i.e., $89 \mathrm{MWh}$ yearly, would be produced. Even when considering the semi-continuous regime, i.e., $12 \mathrm{~h} /$ day, the amount of biogas produced would allow increasing the co-generation unit efficiency $(31 \%)$ and consequently $28 \mathrm{kWe}$ at peak period (during referred $12 \mathrm{~h} /$ day) would be obtained. In this case, the annual electricity production would be as high as $97.5 \mathrm{MWh}$. Still, as the electricity cogeneration unit efficiency is moderate, the analysed case study considers a possibility to generate the cooling energy as a utility for a better preservation of PISCIS products. In such a situation, in a year scale with a $12 \mathrm{~h}$ /day regime, the obtained biogas could allow generating ca. 26.1 MWh/month of cooling energy. Another important aspect of organic wastes and residues valorisation via biogas production is a co-production of digestate. The produced digestate ( $35 \mathrm{~kg}$ /day) can be used as a biofertiliser for agricultural management, bringing benefits for agriculture and improving the environment by replacing the use of artificial fertilisers. Fertilisation of arable fields with digestate is characterised by high bioavailability of nitrogen compounds (nitrogen ammonium), which are easily absorbed by root systems of vegetables and other plants. The most important effect related to the use of digestate is the impact on the increase in the yield of plants fertilised with digestate, which will improve the economic results of agricultural activity and additionally 
reduce the need for mineral fertilisers. This in turn reduces the costs of vegetable or crop production. Simultaneously, the use of digestate reduces the expenditure incurred on agriculture production carried out on the farm.

Besides the cooling energy and biofertiliser production, the collected mass and energy balances allowed determining the economics of the considered case study and the results are resumed in Table 4.

Table 4. Cost-gain balance from the PISCIS production considering the outputs from biogas production facility (monthly scale).

\begin{tabular}{|c|c|c|c|c|c|c|c|}
\hline & \multirow{2}{*}{ Amount } & \multicolumn{2}{|c|}{ Cost } & \multicolumn{2}{|c|}{ Gain } & \multirow{2}{*}{$\begin{array}{c}\text { Profit } \\
€\end{array}$} & \multirow{2}{*}{$\begin{array}{c}\text { Savings } \\
€\end{array}$} \\
\hline & & $€ /$ unit & $€$ & $€ /$ unit & $€$ & & \\
\hline Fish fillets (t) & 4.96 & 1515.15 & 7513.64 & 2727.27 & $13,524.55$ & 6010.91 & \\
\hline Viscera oil (t) & 0.42 & 175.90 & 73.78 & 383.14 & 160.71 & 86.93 & \\
\hline Fish residues ${ }^{a}(t)$ & 9.12 & 4.55 & 0.00 & 0.00 & 0.00 & 0.00 & 41.46 \\
\hline Prawns $(\mathrm{t})$ & 2.00 & 2272.73 & 4545.45 & 3030.30 & 6060.61 & 1515.15 & \\
\hline Prawns residues ${ }^{a}(t)$ & 1.33 & 4.55 & 0.00 & 0.00 & 0.00 & 0.00 & 6.06 \\
\hline Lettuce $(\mathrm{t})$ & 4.76 & 353.50 & 1682.66 & 454.50 & 2163.42 & 480.76 & \\
\hline Lettuce residues ${ }^{a}(t)$ & 1.19 & 4.55 & 0.00 & 0.00 & 0.00 & 0.00 & 5.41 \\
\hline Tomato $(\mathrm{t})$ & 16.67 & 37.08 & 618.01 & 545.45 & 9090.91 & 8472.90 & \\
\hline Tomato residues ${ }^{a}(t)$ & 4.17 & 4.55 & 0.00 & 0.00 & 0.00 & 0.00 & 18.94 \\
\hline Cooling energy (GJ) & 94.08 & 3.69 & 346.90 & 12.63 & 1188.00 & 841.10 & \\
\hline Biofertiliser ${ }^{b}(t)$ & 1.05 & 0.00 & 0.00 & 333.33 & 350.00 & 350.00 & \\
\hline TOTAL & & & $14,780.43$ & & $32,538.19$ & $17,757.76$ & 71.87 \\
\hline
\end{tabular}

${ }^{a}$ residue neutralisation cost; ${ }^{b}$ biofertiliser is a sub-product of the biogas plant; therefore, its production cost is not considered as it is indirectly demonstrated in the production cost of electricity and heat.

The results presented in Table 4 show that main products of PISCIS, i.e., fish fillets, tomato, prawns, etc., are main source of revenues, as they constitute as much as $93 \%$ of all profit. The cooling energy and biofertiliser even together with savings from residue neutralisation avoidance are only a minor part of profit (less than 7\%). This confirms that anaerobic digestion of organic waste is more an environmental commitment with society rather than real source of economic benefits. Consequently, on the basis of this observation, the economic feasibility of the biogas installation was studied taking into account the biogas facility outputs, i.e., cooling energy and fertiliser, as well as on the CAPEX and OPEX. The results of this analysis are presented in Table 5.

As shown in Table 5, overall yearly cost for the first 5 years of running of biogas production facility is $12,858.02 €$ higher than gains from the biogas plant outputs, i.e., cooling energy and biofertiliser as well as avoidance of wastes naturalisation cost. The main reason for this is that the entire investment cost together with a bank loan cost are paid back with the first 5 years of the biogas production plant running. The investment cost constitutes over $71 \%$ of the total annual cost during the first 5 years of operation. Once the bank loan is paid and the investment cost is also depreciated, the economics of the biogas facility changes. The operation cost from the 5 th years on equals to $9032.79 €$ whereas gains are $10 \mathrm{k} €$ higher $(19,318.45 €)$. This change is especially visible analysing the shape of the profit curve, which within the first 5 years of the operation demonstrates a negative slope (slope $=-12.858 \mathrm{k} € /$ year), while starting from the 5 th year, the angle coefficient of profit curve turns to be positive (slope $=10.286 \mathrm{k} € /$ year).

The biogas production gains and costs allowed a calculation of the NPV. The NPV for discount rate (i) $i=0 \%$ and the relation between NPV and various $i$ is given in Figure 4 . The obtained results allowed calculation of IRR that, for the considered case study, is equal to $6.2 \%$. 
Table 5. Economic balance of biogas facility (year scale).

\begin{tabular}{cccc}
\hline & Gain $(\boldsymbol{\epsilon})$ & Cost (€) (Y1-Y5) & $\begin{array}{c}\text { Cost (€) } \\
(\mathbf{Y 6}-\mathbf{Y 2 0})\end{array}$ \\
\hline $\begin{array}{c}\text { Waste neutralisation avoidance } \\
\text { Biogas plant output a }\end{array}$ & 862.45 & & \\
Investment (CAPEX + bank loan cost) & $18,456.00$ & 4162.75 & 4162.75 \\
OPEX & & $23,143.68$ & \\
\hline TOTAL & $19,318.45$ & $32,176.47$ & 4870.04 \\
\hline a cooling energy and biofertiliser. & &
\end{tabular}

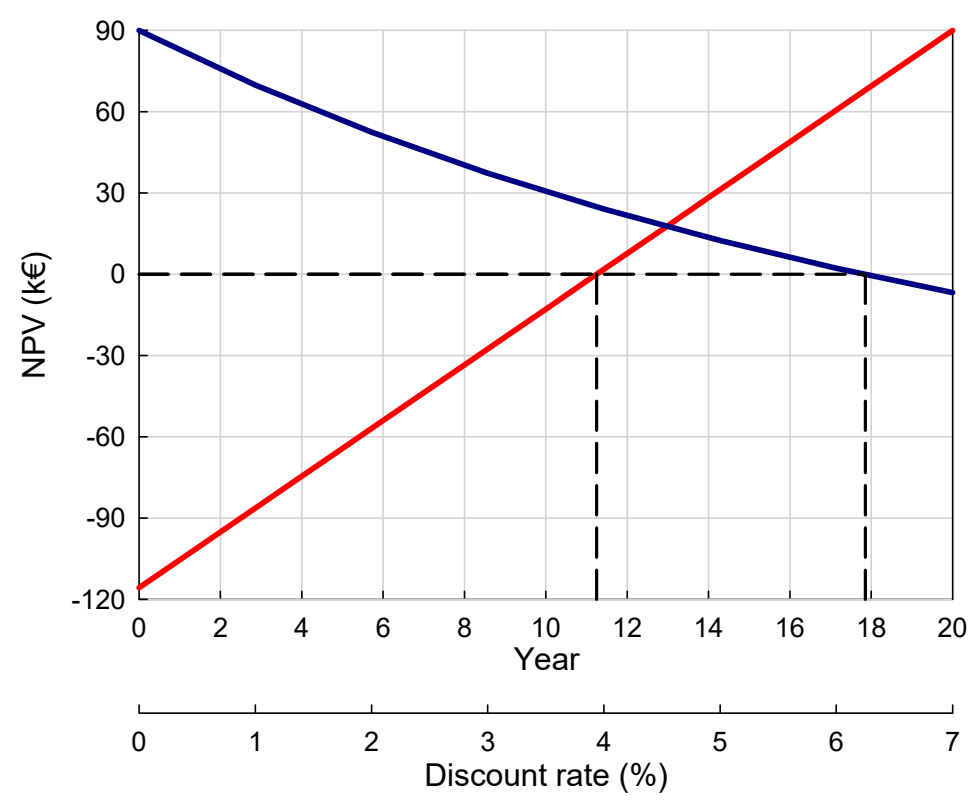

Figure 4. The NPV along the exploitation time (in years) of biogas production facility utilisation (red line) and the NPV function of the discount rate (dark blue line).

Figure 4 demonstrates that NPV starts to be positive after 12th year. Although an 11-year period until getting a positive NPV seems to be long, it is important to state that only cooling energy and biofertiliser obtained from the biogas production facility were considered in the economy analysis. Potential additional gains from the use of cooling energy for improvement of quality of fish derived products, vegetables, and prawns were not contemplated in these considerations. Additionally, as durability of a biogas production facility is a minimum of 20 years, the aforementioned 11-year time span can be considered as encouraging. Furthermore, the accumulated ROI in 20-year time was calculated and is as high as $77.8 \%$, which is comparable to what is presented in literature for biogas production from fish residues and manure ( $\mathrm{ROI}=51 \%$ ) [32]. The obtained results confirm that the considered case study can be a case of success in the Brazilian panorama either from the technological, environmental, or economic point of view. Similar results were also demonstrated in literature for other facilities either for Brazil or for other countries. As already stated, the biogas potential in Brazil is huge, and the main reason for this is that the pool of potential market size is large and the rate of adoption of biogas technology as an approach for the valorisation of wastes and residues is still very low [11]. Furthermore, when the biogas adaptation approach is extended beyond the electricity and biofertiliser production and to include the cooling energy production for industrial use or the renewable natural gas [15], the level of penetration of Brazilian and other markets can be even bigger. Besides the end-use side, also the feedstock side can be widely enlarged by involvement of fish residues [16] beyond the traditional poultry residues, manure [33], and food wastes [34]. It is because the biogas production from fish-type 
feedstock garners more and more attention, chiefly since literature data demonstrates that the biogas production rate from fish is as efficient as from poultry manure, i.e., $370 \mathrm{~mL} / \mathrm{g}$ vs. $390 \mathrm{~mL} / \mathrm{g}$, respectively [35]. When analysing the specific fish residues, Fonseca et al. went even further and reported the biogas and methane production for all types of tilapia processing residues. After fillet separation, the remaining part of the tilapia were head (26.4 wt.\%), carcass (15.3 wt.\%), viscera (7.3 wt.\%), fin (9 wt.\%), skin (3.7 wt.\%), and scale (2.9 wt.\%). The highest biogas productivity was observed for viscera $(402 \mathrm{~L} / \mathrm{kg}$ of fresh matter), whereas considering the fresh matter content per amount of specific type of residues, the highest potential lies in heads and carcasses with 261 and $222 \mathrm{~L} / \mathrm{kg}$ of fresh matter, respectively. For a mixture of all tilapia residues, the cumulative biogas production was as high as $258 \mathrm{~L} / \mathrm{kg}$ of fresh matter, and methane content was $125 \mathrm{~L} / \mathrm{kg}$ of fresh matter [30]. Similar results were reported by others [16] proving that the head of tilapia reveals the highest methane production of $321 \mathrm{~mL} / \mathrm{g}$ COD (chemical oxygen demand), while fish residues in total showed the methane potential as high as $308 \mathrm{~mL} / \mathrm{g}$ COD. This data confirm that use of tilapia residues from fish filleting and viscera oil production wastes are interesting raw material for valorisation via biogas production.

From a wider perspective, either in Brazil or in other countries, biogas production can be seen as a part of the broader concept. For example, Winquist et al. determined four main reasons for biogas strategy deployment. They are environmental services, source of biofertiliser and biochemicals, energy production, and GHG emission reduction with an improvement of air quality, especially in cities [36]. In this context, use of biogas as a part of a circular economy with production of value-added commodities and/or utilities as cooling energy is the most attractive option in zero-waste approach [37,38]. Nevertheless, biogas is currently mainly used to produce electricity and heat. Encouraged by the implemented renewable energy policies (incl. more than 200 support schemes and incentives), the EU has become the world leader in biogas electricity production with more than $10 \mathrm{GW}$ installed in 2015 [39]. However, significant cost reductions for wind and solar photovoltaics and their better environmental performances affect the future potential for biogas use in the electricity sector [40]. In various member states (incl. the Netherlands, Germany, and Italy), this results in support schemes for biogas electricity production falling short in the competition with wind and solar. In addition, in some countries, such schemes are even expiring without successors being introduced. One of the applications might be the use of biomethane as transport fuel [41] because long-haul transport segments such as the maritime industry are hard to electrify in a short-to-medium term, and, as such, they offer an ideal destination for the valorisation of the available biogas streams [42] Furthermore, the maritime industry will soon be included in the EU's climate action policies and regulations by which the demand for sustainable solutions will grow significantly. In addition, biomethane produced via anaerobic digestion has tremendous potential to contribute to meet the Paris Agreement goals [43]. Especially with increased deployment of other renewable energy technologies and the shift away from coal in energy generation, the emission factors of the grid energy are likely to improve. This will counterbalance the unit GHG-abatement benefit from energy generation via anaerobic digestion, especially since use of biogas contributes to GHG abatement in a number of forms: avoided emissions from fossil fuel burning, avoided emissions from inorganic fertiliser manufacture, avoided landfill emissions from food waste digestion, avoided emissions from manure management, and avoided emissions from burning of crops. Based on the aforementioned considerations, a SWOT (strengths, weaknesses, opportunities, and threats) analysis was performed, and the result is presented in Table 6. The SWOT analysis demonstrates that the strength of these technologies provides a way for sustainable management of organic waste and, at the same time, reveals the most environmentally beneficial technology for bioenergy production. The weaknesses related to the effective and efficient performance of the process control also yield stability depending on the process. There are several opportunities that could contribute to the decrease of these weaknesses and the avoidance of some of the threats, among which is a high, unexploited potential and a broad range of potential 
applications associated to the accomplishment of the national and international climate and energy-related goals.

Table 6. The SWOT analysis of biogas implementation, prepared on the basis of this work and results presented elsewhere [44-47].

\begin{tabular}{|c|c|}
\hline Strengths & Weaknesses \\
\hline $\begin{array}{l}\text { Availability of the raw material (organic waste) on a local scale, } \\
\text { without the need to use any emission-related transportation }\end{array}$ & Moderate to high investment cost, requiring a bank loan \\
\hline Decreasing the negative environmental impact of organic waste & $\begin{array}{l}\text { Long payback period, difficult to operationalize for a } \\
\text { small business }\end{array}$ \\
\hline $\begin{array}{l}\text { Lowering GHG emissions thanks to production of energy from } \\
\text { organic waste instead of using electricity from the electricity } \\
\text { grid, mainly in Brazil produced from crude oil }\end{array}$ & $\begin{array}{l}\text { The profitability of the planned investment longer than } 2 \text { years } \\
\text { is unpredictable in condition of small Brazilian company }\end{array}$ \\
\hline $\begin{array}{c}\text { Environmentally friendly waste management in a small } \\
\text { company and avoiding contamination of water and soil with } \\
\text { post-production organic waste }\end{array}$ & $\begin{array}{l}\text { The introduction of technological and organizational } \\
\text { innovations, generating many challenges for the company }\end{array}$ \\
\hline $\begin{array}{l}\text { Closing the production cycle accordingly to the circular economy } \\
\text { paradigm with the use of bio-waste and any organic residues }\end{array}$ & $\begin{array}{l}\text { The need to take a business risk when the company's financial } \\
\text { resources are limited }\end{array}$ \\
\hline $\begin{array}{l}\text { Diversification of the company production and introduction to } \\
\text { the market a new product-a natural fertiliser, produced as a } \\
\text { by-product of biogas production }\end{array}$ & $\begin{array}{l}\text { Lack of sufficiently qualified staff in the field of bioprocesses } \\
\text { and biogas production control }\end{array}$ \\
\hline $\begin{array}{l}\text { Building the company's energy independence and energy } \\
\text { security of production, sensitive to temperature rise }\end{array}$ & $\begin{array}{l}\text { Lack of knowledge and experience of management in the field } \\
\text { of the new business model }\end{array}$ \\
\hline $\begin{array}{l}\text { Self-sufficiency in terms of clean, green energy } \\
\text { provision for cooling }\end{array}$ & Hardly profitable for small scale of biogas production \\
\hline $\begin{array}{l}\text { Increasing the company staff's competences with bioprocess } \\
\text { skills and logistics and biogas production processes control }\end{array}$ & $\begin{array}{l}\text { Inconvenient location of the biogas plant in context of its } \\
\text { possible development and expansion due to the large distance } \\
\text { from other agri-food producers and potential providers of } \\
\text { source for biogas production }\end{array}$ \\
\hline
\end{tabular}

Building a positive image of the company as modern and environmentally friendly, which will translate into the company's business position
The need to integrate the gas production process technology line with the company's production complex
Joining the implementation of national and international
climate and energy goals

Joining the implementation of national and
climate and energy goals

\begin{tabular}{c}
\hline Opportunities \\
\hline $\begin{array}{c}\text { Well-known and tested technology for large- and medium-scale } \\
\text { biogas production }\end{array}$ \\
\hline
\end{tabular}

Alternative to fossil energy sources
Different yield of biogas production for different feedstock

\section{No direct control of the system performance}

Technological difficulties in management, control, and stabilization of the technology of small-scale biogas production from feedstock with variable composition

\begin{tabular}{cc}
\hline Alternative to fossil energy sources & $\begin{array}{c}\text { Relatively low level of innovation in biogas production } \\
\text { technology }\end{array}$ \\
\hline Broad range of potential applications of biogas and fertilisers & No ground-breaking innovations in scope of biogas technology \\
\hline $\begin{array}{c}\text { Decentralisation of energy production, shortening the energy } \\
\text { transportation and relieving the Brazilian energy grids }\end{array}$ & $\begin{array}{c}\text { Limited subsidies and grants in Brazil (including those from EU } \\
\text { and overseas) }\end{array}$ \\
\hline $\begin{array}{c}\text { Raising the global and Brazilian awareness of importance of } \\
\text { national and international climate and energy-related } \\
\text { goals implementation }\end{array}$ & Other renewable energy sources \\
\hline High unexploited potential of Brazilian agro-food companies & $\begin{array}{c}\text { Low to moderate level of social awareness of potential of biogas } \\
\text { production }\end{array}$ \\
\hline
\end{tabular}


Table 6. Cont.

\begin{tabular}{|c|c|}
\hline Opportunities & Threats \\
\hline $\begin{array}{l}\text { Regional and rural development thanks to the implementation } \\
\text { of circular economy on a local scale }\end{array}$ & Legal restrictions on use of biofertiliser \\
\hline $\begin{array}{l}\text { Acceleration and development of realization of national climate } \\
\text { and energy goals }\end{array}$ & Low price of fossil counterparts \\
\hline $\begin{array}{l}\text { Mitigation of global climate changes. Protection of soil, water, } \\
\text { and oceans }\end{array}$ & $\begin{array}{l}\text { Ongoing research/no satisfying technological } \\
\text { recommendations/in scope of problems of management, } \\
\text { control, and stabilization of the technology of small-scale biogas } \\
\text { production with a variable composition of organic substrates }\end{array}$ \\
\hline \multicolumn{2}{|l|}{$\begin{array}{l}\text { Chances to create cooperation networks and energy } \\
\text { cooperatives on biogas production on local scale }\end{array}$} \\
\hline \multicolumn{2}{|l|}{$\begin{array}{l}\text { Possibility of benefitting grants or subsidies from external } \\
\text { financing sources dedicated to mitigation of climate changes }\end{array}$} \\
\hline $\begin{array}{l}\text { Possibility to take advantage of the European experience within } \\
\text { the framework of EU aid programmes and the Green } \\
\text { Deal initiatives }\end{array}$ & \\
\hline
\end{tabular}

In addition to SWOT analysis, a political, economic, social, and technological (PEST) analysis was made considering the factors affecting the implementation of biogas. The result of it is described in detail in Table 7.

Table 7. The PEST analysis of biogas implementation, prepared on the basis of this work and results presented elsewhere $[7,44-46,48,49]$.

\begin{tabular}{|c|c|}
\hline Political & Economic \\
\hline $\begin{array}{l}\text { Green light for renewable energy sources development on } \\
\text { global, national, regional, and local levels }\end{array}$ & $\begin{array}{l}\text { Implementation of circular economy paradigm in practice of } \\
\text { small Brazilian company }\end{array}$ \\
\hline Biowaste treatment regulations & $\begin{array}{l}\text { The need to compete with other renewable energy sources in } \\
\text { terms of profitability }\end{array}$ \\
\hline $\begin{array}{l}\text { Long-term energy tariffs and electricity prices, } \\
\text { development-friendly green energy }\end{array}$ & Energy independence in local scale \\
\hline Political efforts to mitigate climate change & Diversifying the production of small agri-food companies \\
\hline Permits needed for the use of bioproducts & $\begin{array}{c}\text { Widely distributed technology contributing to local } \\
\text { development }\end{array}$ \\
\hline $\begin{array}{l}\text { National and international climate and energy obligation (e.g., } \\
\text { Paris Agreement [43], RED II [50]) }\end{array}$ & Entrepreneurship development \\
\hline Social & Technical \\
\hline $\begin{array}{l}\text { Lighthouse for the sustainable development of local societies in } \\
\text { Brazil }\end{array}$ & $\begin{array}{l}\text { Increasing the technological advancement of agri-food } \\
\text { companies }\end{array}$ \\
\hline $\begin{array}{l}\text { Waste recycling in circular processes, engaging local } \\
\text { communities }\end{array}$ & Development of new pre-treatment methods \\
\hline $\begin{array}{l}\text { Raising the knowledge and competences of managers and } \\
\text { employees of small agri-food companies }\end{array}$ & Coupling with other more advanced application \\
\hline $\begin{array}{l}\text { Social responsibility for the condition of the natural } \\
\text { environment }\end{array}$ & Increase in methane content in biogas \\
\hline Social local networks for development of green economy & $\begin{array}{c}\text { Limited knowledge about the specificity of biological processes } \\
\text { occurring in the anaerobic digestion }\end{array}$ \\
\hline Use of renewable energy sources in ev & \\
\hline
\end{tabular}


Regarding the economic and technological factors affecting the technologies for biogas production, the most important ones are that there are large quantities of resources (organic waste) for these technologies and a good background for investment and innovations in the sector in new systems for control and pre-treatment methods. On the other hand, other more profitable opportunities for investments in renewable energy sources coupled with current electricity prices are the main barriers in wide biogas implementation.

\section{Conclusions}

This work presents the potential valorisation of wastes from the agro-industrial company directly affected by the climate changes strongly noticed in Brazil. The potential implementation of the proposed action drives to the reduction of yearly burden on the environment with organic waste in the amount of 189.74 of tonnes yearly and production of $94.08 \mathrm{GJ}$ of cooling energy and 1.05 tonnes of biofertiliser monthly. As the Ceará region is affected by climate changes, the valorisation of the agriculture and aquaculture wastes and residues is of the greatest importance for environment protection, whereas the main activity of PISCIS is production of viscera oil, tilapia fillets, prawns, lettuce, and tomato.

Waste management utilization of environmentally friendly technologies should improve the quality of business not only for the specific company, but also it will be a lighthouse for other Ceará region food-processing companies. Furthermore, the presented systemic approach of small-scale biogas production and the production of fertilisers using agri- and aquaculture wastes and residues by a small company in Brazil can be a significant stimulus for transformations in low-efficiency and low-technology sectors of the economy in countries with a low or average level of development, such as Brazil. The use of any organic waste for electricity generation can be seen from the perspective of environmental advantage, namely a reduction of waste in landfills and in the ocean, an increase in economic effectiveness, and production stability, i.e., saving cost of energy, reducing volume of transport fuels, and the reduction of $\mathrm{CO}_{2}$ emissions.

The challenge for the scientific community, but above all for the global economic ecosystem, is therefore to answer the question of how to properly develop economic activity in low-income countries in accordance with the circular economy paradigm without draining natural resources. It is of a particular relevance now, when a pandemic situation is introducing a new model of life for societies that is more reliant on local production capacities exploiting endogenous resources rather than on global markets with long worldwide production chains.

Author Contributions: Conceptualization, J.X., E.K. and R.M.Ł.; methodology, J.X., A.S., E.K. and R.M.Ł.; validation, J.X., A.S., E.K. and R.M.Ł.; formal analysis, J.X., A.S., E.K. and R.M.E.; investigation, J.X., E.K. and R.M.Ł.; resources, A.S. and E.K.; data curation, J.X., E.K. and R.M.E.; writing-original draft preparation, J.X., A.S., E.K. and R.M.Ł.; writing-review and editing, J.X., A.S., E.K. and R.M.Ł.; visualization, E.K. and R.M.Ł.; supervision, A.S. and E.K.; project administration, A.S. and E.K.; funding acquisition, A.S. and E.K. All authors have read and agreed to the published version of the manuscript.

Funding: This work was supported by the Low Carbon Business Action in Brazil (contract number 81235201, project processing number 67.3039.4-001.00) funded by the European Union to support the transition of small and medium-sized enterprises (SMEs) to the low carbon economy.

Institutional Review Board Statement: Not applicable.

Informed Consent Statement: Not applicable.

Data Availability Statement: The data presented in this study are available on request from the corresponding author.

Conflicts of Interest: The authors declare no conflict of interest.

\section{References}

1. De Oliveira, M. Tilapia's turn. Pesqui. FAPESP 2016, 249, 67-71. 
2. Iastiaque Martins, G.; Secco, D.; Tokura, L.K.; Bariccatti, R.A.; Dolci, B.D.; Santos, R.F. Potential of tilapia oil and waste in biodiesel production. Renew. Sustain. Energy Rev. 2015, 42, 234-239. [CrossRef]

3. Silva, J.F.X.; Ribeiro, K.; Silva, J.F.; Cahú, T.B.; Bezerra, R.S. Utilization of tilapia processing waste for the production of fish protein hydrolysate. Anim. Feed Sci. Technol. 2014, 196, 96-106. [CrossRef]

4. Portal Hidrológico do Ceará. Available online: http:/ / www.hidro.ce.gov.br/ (accessed on 1 April 2021).

5. Volume do Castanhão Aumenta 21\% Nesta Quadra Chuvosa. Available online: http://www.opovo.com.br/jornal/cidades/2019 /04/08/volume-do-castanhao-aumenta-21--nesta-quadra-chuvosa.html (accessed on 1 April 2021).

6. Mortandade de Peixe Gera Prejuízo de R\$18 Milhões no Castanhão, no CE. Available online: http:/ /g1.globo.com/ceara/noticia/ 2015/07/mortandade-de-peixe-gera-prejuizo-de-r-18-milhoes-no-castanhao-no-ce.html (accessed on 1 April 2021).

7. Kochańska, E. Selected problems of water, electricity and waste management in Brazil in the context of its impact on climate change mitigation. Acta Innov. 2019, 29-39. [CrossRef]

8. Lopes, T.F.; Łukasik, R.M. Economic, social and environmental impacts attained by the use of the effluents generated within a small-scale biorefinery concept. Acta Innov. 2020, 57-63. [CrossRef]

9. De Oliveira, L.G.S.; Negro, S.O. Contextual structures and interaction dynamics in the Brazilian Biogas Innovation System. Renew. Sustain. Energy Rev. 2019, 107, 462-481. [CrossRef]

10. Silva dos Santos, I.F.; Braz Vieira, N.D.; de Nóbrega, L.G.B.; Barros, R.M.; Tiago Filho, G.L. Assessment of potential biogas production from multiple organic wastes in Brazil: Impact on energy generation, use, and emissions abatement. Resour. Conserv. Recycl. 2018, 131, 54-63. [CrossRef]

11. Borges, C.P.; Sobczak, J.C.; Silberg, T.R.; Uriona-Maldonado, M.; Vaz, C.R. A systems modeling approach to estimate biogas potential from biomass sources in Brazil. Renew. Sustain. Energy Rev. 2021, 138, 110518. [CrossRef]

12. Campello, L.D.; Barros, R.M.; Tiago Filho, G.L.; dos Santos, I.F.S. Analysis of the economic viability of the use of biogas produced in wastewater treatment plants to generate electrical energy. Environ. Dev. Sustain. 2021, 23, 2614-2629. [CrossRef]

13. Wattanasilp, C.; Songprakorp, R.; Nopharatana, A.; Khompatraporn, C. Techno-Cost-Benefit Analysis of Biogas Production from Industrial Cassava Starch Wastewater in Thailand for Optimal Utilization with Energy Storage. Energies 2021, 14, 416. [CrossRef]

14. Piwowar, A. Agricultural biogas-an important element in the circular and low-carbon development in Poland. Energies 2020, 13, 1733. [CrossRef]

15. Assunção, L.R.C.; Mendes, P.A.S.; Matos, S.; Borschiver, S. Technology roadmap of renewable natural gas: Identifying trends for research and development to improve biogas upgrading technology management. Appl. Energy 2021, 292, 116849. [CrossRef]

16. Donoso-Bravo, A.; Bindels, F.; Gerin, P.A.; Vande Wouwer, A. Anaerobic biodegradability of fish remains: Experimental investigation and parameter estimation. Water Sci. Technol. 2015, 71, 922-928. [CrossRef] [PubMed]

17. Ceará-Energy Supply System. Federação das Industrias do Estado do Ceará. 2019. Available online: https://www1.sfiec.org.br/ (accessed on 1 April 2021).

18. Więckowski, A. Bio-Tec Sp. z o.o. Sp. K. Unpublished Data. 2019.

19. Ximenes, J. Data Collected from PISCIS Industrial Activities. Unpublished Data. 2020.

20. Agrolink. Available online: https://www.agrolink.com.br/cotacoes/ (accessed on 1 April 2021).

21. Biomethane. Available online: https://mediathek.fnr.de/broschuren/fremdsprachige-publikationen/english-books/biomethane. html (accessed on 1 April 2021).

22. GloboRural Fertilizante: Alto Preço Atrasa Comercialização da Safra 2019/2020. Available online: https: / / revistagloborural.globo. com/Noticias / Agricultura/Soja/noticia/2019/05/fertilizante-alto-preco-atrasa-comercializacao-da-safra-20192020.html (accessed on 1 April 2021).

23. Arvanitoyannis, I.S.; Kassaveti, A. Fish industry waste: Treatments, environmental impacts, current and potential uses. Int. J. Food Sci. Technol. 2008, 43, 726-745. [CrossRef]

24. Carvalho, G.G.P. de; Pires, A.J.V.; Veloso, C.M.; da Silva, F.F.; de Carvalho, B.M.A. Silagem de resíduo de peixes em dietas para alevinos de tilápia-do-nilo. Rev. Bras. Zootec. 2006, 35, 126-130. [CrossRef]

25. De Freitas Siqueira, A. Desenvolvimento de Sistema Para Digestão com Uso de Efluentes Residuais do Processamento das Vísceras de Tílapia do Nilo (Oreochromis Niloticus) e Carcaças de Peixes Mortos; PISCIS Indústria e Comércio Ltda.: Jaguaribara, Brazil, 2016.

26. Rødde, R.H.; Einbu, A.; Vårum, K.M. A seasonal study of the chemical composition and chitin quality of shrimp shells obtained from northern shrimp (Pandalus borealis). Carbohydr. Polym. 2008, 71, 388-393. [CrossRef]

27. Agius, C. The Yield and Quality of Lettuce Crop, Grown in Different Growing Media. Bachelor's Thesis, University of Malta, Msida, Malta, 2015.

28. Yeshiwas, Y.; Belew, D.; Tolessa, K. Tomato (Solanum lycopersicum L.) Yield and Fruit Quality Attributes as Affected by Varieties and Growth Conditions. World J. Agric. Sci. 2016, 12, 404-408.

29. Biogas-An Introduction. Available online: https://mediathek.fnr.de/broschuren/fremdsprachige-publikationen/englishbooks/biogas-an-introduction.html (accessed on 1 April 2021).

30. Fonseca, C.; Frare, L.M.; D'avila, L.; Edwiges, T. Influence of different waste compositions from tilapia fish on methane production. J. Clean. Prod. 2020, 265, 121795. [CrossRef]

31. Kafle, G.K.; Kim, S.H. Evaluation of the Biogas Productivity Potential of Fish Waste: A Lab Scale Batch Study. J. Biosyst. Eng. 2013. [CrossRef] 
32. Venslauskas, K.; Navickas, K.; Nappa, M.; Kangas, P.; Mozūraitytė, R.; Šližytė, R.; Župerka, V. Energetic and economic evaluation of zero-waste fish co-stream processing. Int. J. Environ. Res. Public Health 2021, 18, 2358. [CrossRef]

33. Johannesson, G.H.; Crolla, A.; Lauzon, J.D.; Gilroyed, B.H. Estimation of biogas co-production potential from liquid dairy manure, dissolved air flotation waste (DAF) and dry poultry manure using biochemical methane potential (BMP) assay. Biocatal. Agric. Biotechnol. 2020, 25, 101605. [CrossRef]

34. Iwaszczuk, N.; Szyba, M.; Iwaszczuk, A.; Yakubiv, V. Production of agricultural biogas from waste-An element of socially responsible actions in the food sector. Acta Innov. 2019, 52-62. [CrossRef]

35. Jos, B.; Sucipto, T.A.; Pramianshar, A.; Ikrimah, A.N.; Sumardiono, S. Experimental and kinetic study of biogas production of fish processing industry in anaerobic digestion as future renewable energy resources. AIP Conf. Proc. 2020, $2197,030013$.

36. Winquist, E.; Rikkonen, P.; Pyysiäinen, J.; Varho, V. Is biogas an energy or a sustainability product?-Business opportunities in the Finnish biogas branch. J. Clean. Prod. 2019, 233, 1344-1354. [CrossRef]

37. Manzanares, P. The role of biorefinering research in the development of a modern bioeconomy. Acta Innov. 2020, 47-56. [CrossRef]

38. Morone, P.; Yilan, G. A paradigm shift in sustainability: From lines to circles. Acta Innov. 2020, 5-16. [CrossRef]

39. Scarlat, N.; Dallemand, J.F.; Fahl, F. Biogas: Developments and perspectives in Europe. Renew. Energy 2018, 129, 457-472. [CrossRef]

40. Banja, M.; Jégard, M.; Motola, V.; Sikkema, R. Support for biogas in the EU electricity sector-A comparative analysis. Biomass Bioenergy 2019, 128, 105313. [CrossRef]

41. Owczuk, M.; Matuszewska, A.; Kruczyński, S.; Kamela, W. Evaluation of using biogas to supply the dual fuel diesel engine of an agricultural tractor. Energies 2019, 12, 1071. [CrossRef]

42. Kesieme, U.; Pazouki, K.; Murphy, A.; Chrysanthou, A. Biofuel as an alternative shipping fuel: Technological, environmental and economic assessment. Sustain. Energy Fuels 2019, 3, 899-909. [CrossRef]

43. Paris Agreement. In Proceedings of the 21st Conference of the Parties (COP) of the United Nations Framework Convention on Climate Change, Paris, France, 30 November-12 December 2015.

44. Taleghani, G.; Kia, A.S. Technical-economical analysis of the Saveh biogas power plant. Renew. Energy 2005, 30, 441-446. [CrossRef]

45. Escribano, A.J. Transitions toward sustainability in the livestock business: Developing countries and disfavored areas. In Business Infrastructure for Sustainability in Developing Economies; IGI Global: Hershey, PA, USA, 2016; pp. 192-214. ISBN 9781522520429.

46. Janas, M.; Zawadzka, A. Assessment of environmental impact of agricultural biogas plant. Acta Innov. 2018, 27, 24-31. [CrossRef]

47. Piechota, G.; Igliński, B. Biomethane in Poland-Current Status, Potential, Perspective and Development. Energies 2021, $14,1517$. [CrossRef]

48. Budzianowski, W.M. Sustainable biogas energy in Poland: Prospects and challenges. Renew. Sustain. Energy Rev. 2012, 16, 342-349. [CrossRef]

49. Khalid, H.; Zhang, H.; Liu, C.; Li, W.; Abuzar, M.K.; Amin, F.R.; Liu, G.; Chen, C. PEST (political, environmental, social \& technical) analysis of the development of the waste-to-energy anaerobic digestion industry in China as a representative for developing countries. Sustain. Energy Fuels 2020, 4, 1048-1062.

50. European Commission. Directive (EU) 2018/2001 of the European Parliament and of the Council of 11 December 2018 on the promotion of the use of energy from renewable sources. Off. J. Eur. Union 2018, OJL 328, 82-209. 